\title{
A BIBLIOMETRIC ANALYSIS ON DEPENDENCY THEORY
}

\author{
Saleh Md ARMAN1 \\ Tazin AHMED 2 \\ DOI: https://doi.org/10.35782/JCPP.2021.4.07
}

\begin{abstract}
Dependency theory, established after World War II, is a popular theory among economists to portray the relationship between the underdeveloped and the developed countries that conditions the ability of the underdeveloped countries to develop. Several concepts have been merged into this area from different corners, making it interdisciplinary. As a lucrative area of interest in research, the study would like to assess how the concept of dependency theory has been widely accepted among authors from different corners and schools of thoughts and how their research outputs make a significant notation in this area. The research conducted a bibliometric analysis on dependency theory. 1074 Scopus indexed documents in English were considered. The study covered the two pillars of bibliography analysis: performance analysis and science mapping. The study used several formulas to calculate parameters of performance analysis and availed V osviewer software to make maps of science-mapping analysis. The study concluded that dependency theory is a significant theory in economics and has significant implications in different research publications. This bibliometric analysis surfaces the significance of this theory which would attract researchers in incorporating more interdisciplinary research.
\end{abstract}

Keywords: bibliometric analysis; dependency theory; performance analysis; science mapping; interdisciplinary research

\section{Introduction and Problem Background}

In the context of economic aspects, countries are being classified under several categories (i.e.: 'elitist' and 'peripheral', see Roşca, 2017; or 'central' or 'peripheral', see Roşca 2018a, 2018b); the level of development (i.e. 'developed' and 'underdeveloped') represents one of the most significant classifications

(United Nations Secretariat (UN DESA), 2021). The relationship among the countries that belong to those classifications gains attention with scholars of different

1 Assistant Professor, DBA, International University of Scholars, Bangladesh, e-mail: salehmd. arman@gmail.com

2 Lecturer, DBA, International University of Scholars, Bangladesh, e-mail: tazinahmed@ ius.edu.bd 
specializations. Based on their research, the scholars propose different theories that portray the relationship between countries. The Dependency Theory, developed in the 1950's in two papers - one by Hans Singer and the other by Raúl Prebisch (Arezki et al., 2013; Harvey et al., 2010; Roşca, 2018c) - is one of them. According to Ferraro (2019), Prebisch's consideration was that, poor countries exported primary commodities to the rich countries who then manufactured products out of those commodities and sold them back to the poorer countries and therefore, poorer countries would never be earning enough from their export earnings to pay for their imports. The main consideration to dependency theory as a solution to this problem is that poorer countries should embark on programs of import substitution so that they do not need to purchase the manufactured products from the richer countries (Ferraro, 2019). The relation of interdependence between two or more economies, and between these and world trade, assumes the form of dependence when some countries (the dominant ones) can expand and can be self-starting while other countries (the dependent ones) can do this only as a reflection of that expansion which can have either a positive or a negative effect on their immediate development (Dos Santos, 1970).

Dependency theory is a crucial theory in doing different analyses on a particular country's economic state and how its dependency on other countries. Several concepts have been merged into this area from different corners of the world which made this area as interdisciplinary. As a lucrative area of interest in research, the study would like to assess how the concept of dependency theory have been widely accepted among authors from different corners and schools of thoughts and how their research outputs make a significant notation in this area. In this aspect, a bibliometric analysis is used, a notable method of conducting literature review for uncovering the emerging trends in article and journal performance of any field, e.g., dependency theory, collaboration patterns, and research constituents, and to explore the intellectual structure of a specific domain in the existent literature of dependency theory (Donthu et al. 2021).

Scholars have yet to determine the amount or quality of research conducted in the area of dependency theory. So, the interconnection of different research fields in the light of dependency theory is, thus, the expression of interest in conducting a bibliometric analysis which portrays the research areas with the greatest research output, the countries and languages responsible for most dependency theory research, the year in which research on dependency theory began, the journals that publish most research in this area, and the most relevant authors with publications on dependency theory. Bibliometric analysis allows researchers to evaluate developments in knowledge on a specific subject and assesses the scientific influence of researches and sources (Bouyssou and Marchant, 2011). This analysis satisfies both quantitative and qualitative inquiries by summarizing large quantities of bibliometric data to present the state of the intellectual structure and emerging trends of dependency theory (Donthu et al., 2021, p. 287). According to Donthu et al. (2021, p. 285), the bibliometric analysis can facilitate dependency theory domain in order to (1) gain a one-stop overview of this theory, (2) identify knowledge gaps, (3) derive novel ideas for further investigation, and (4) position their intended contributions to the field of dependency theory. 
100 | A bibliometric analysis on dependency theory

Based on the published papers in Scopus, two research questions are developed:

RQ1: How does the performance analysis of Scopus documents reflect the contribution of dependency theory research?

RQ2: How does the science mapping of Scopus documents portray the relationships between dependency theory and other disciplines?

\section{Method}

Bibliometric analysis is a sequential step to derive a result out of any concept, e.g., dependency theory (Brereton et al., 2007; Donthu et al., 2021 and Norouzi et al., 2021). The metrics that we have used in conducting bibliometric analysis are presented in Table 1.

Table 1: Metrics used in conducting the bibliometric analysis on Dependency Theory

\begin{tabular}{|c|c|}
\hline NAME OF METRICS & FORMULAS \\
\hline $\begin{array}{l}\text { CiteScore at Scopus } \\
\text { (4 year window) } \\
\text { (Scopus, 2021) }\end{array}$ & $\begin{array}{l}\text { Citation received in a four year window } \div \text { Published } \\
\text { documents in a four year window } \\
\text { Here } \\
\text { Four year window }=\text { the } 2020 \text { CiteScore counts the } \\
\text { citations received in } 2017-2020 \text {. }\end{array}$ \\
\hline $\begin{array}{l}\text { SJR (Scimago Journal Rank) } \\
\text { (Scimago Lab, 2021) }\end{array}$ & $\begin{array}{l}\text { Average number of weighted citation received in a year } \\
\text { / Number of documents published in previous } 3 \text { years }\end{array}$ \\
\hline $\begin{array}{l}\text { Field Weighted Citation Impact } \\
\text { (FWCI) (Scopus, 2021) }\end{array}$ & $\begin{array}{l}\text { Field-Weighted Citation Impact shows how well cited } \\
\text { this document is when compared to similar documents. } \\
\text { A value greater than } 1.00 \text { means the document is more } \\
\text { cited than expected according to the average. }\end{array}$ \\
\hline $\begin{array}{l}\text { Productivity per active year of } \\
\text { publication (PAY) }\end{array}$ & $\begin{array}{l}\text { Total publications (TP) } \div \text { Number of active years of } \\
\text { publication (NAY) }\end{array}$ \\
\hline Average citations (AC) & Total citations $(\mathrm{TC}) \div$ Number of years \\
\hline Collaboration index (CI) & $\begin{array}{l}(\mathrm{NCA} \div \mathrm{TP}) \div \mathrm{TP} \\
\text { Here, } \\
\mathrm{NCA}=\text { Number of contributing authors }\end{array}$ \\
\hline Collaboration coefficient (CC) & $1-(\mathrm{TP} \div \mathrm{NCA})$ \\
\hline $\begin{array}{l}\text { Proportion of cited publications } \\
\text { (PCP) }\end{array}$ & $\begin{array}{l}\text { NCP } \div \text { TP } \\
\text { Here, } \\
\text { NCP }=\text { Number of cited publications }\end{array}$ \\
\hline h-index (Hirsch, 2005) & $\begin{array}{l}b \text { number of publications of a discipline cite at } \\
\text { least } b \text { times }\end{array}$ \\
\hline g-index (Egghe, 2006) & $\begin{array}{l}g \text { number of publications of a chosen discipline receive } \\
\text { at least } g^{2} \text { citations }\end{array}$ \\
\hline i-10 index (Eldermire, 2021) & $i$ number of publications cited at least $i$ times \\
\hline
\end{tabular}

Source: Donthu et al., 2021, p. 289 


\section{Bibliometric analysis of Dependency Theory}

\subsection{Performance Analysis}

1160 publications on Dependency Theory were available at Scopus at the moment of conducting the research. We only considered papers in final and which were written in English. Those filters reduced the number of dependency theory documents to 1074 (ranging from 1964 to June 21st, 2021), as charted in Figure 1.

Figure 1: Documents by year published at Scopus database

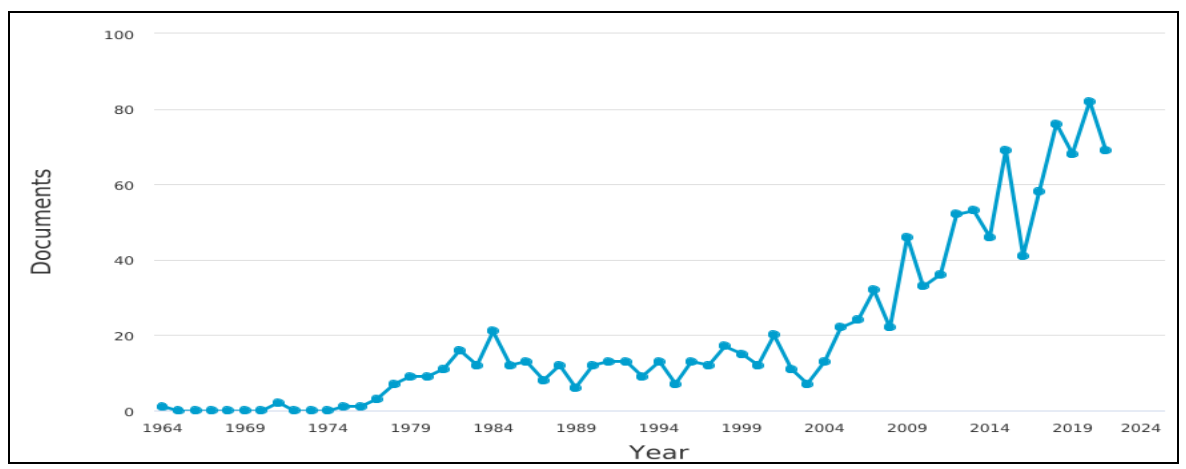

Source: Scopus database

Communication Research and International Journal of Human Resource Management took the lead of 8 publications in each year. Table 2 presented the CiteScore metric at Scopus of the top 10 sources and same as previous, the Journal of Developing Studies took the lead with 9.4 in 2020.

Table 2: CiteScore publication by year

\begin{tabular}{|c|c|c|c|c|c|c|c|c|c|c|}
\hline Source at Scopus & 2011 & 2012 & 2013 & 2014 & 2015 & 2016 & 2017 & 2018 & 2019 & 2020 \\
\hline Communication Research & 4.1 & 4.4 & 4.7 & 4.9 & 4.6 & 5.3 & 6.6 & 6.1 & 7.4 & 9.4 \\
\hline International Journal of Human Resource Management & 1.8 & 1.7 & 1.9 & 2.3 & 3 & 3.9 & 4.4 & 4.3 & 5.5 & 6.9 \\
\hline Journal of Developing Societies & 0.5 & 0.5 & 0.6 & 1 & 1 & 0.8 & 0.9 & 1.2 & 1.5 & 1.3 \\
\hline Review of African Political Economy & 1.3 & 1.3 & 1.8 & 2.1 & 2 & 2 & 1.9 & 2.2 & 2.1 & 1.9 \\
\hline Corporate Governance (Bingley) & 1.1 & 1.2 & 1.3 & 1.3 & 1.5 & 1.7 & 1.7 & 2.6 & 3.3 & 4.1 \\
\hline
\end{tabular}


102 | A bibliometric analysis on dependency theory

Table 3 represents the list of most contributors on Dependency Theory with author hindex.

Table 3: Documents by authors

\begin{tabular}{|l|c|c|}
\hline \multicolumn{1}{|c|}{ Author name } & Number of documents & b-Index \\
\hline Shandra, J.M. & 10 & 18 \\
\hline London, B. & 8 & 21 \\
\hline Tausch, A. & 7 & 6 \\
\hline Williamson, J.B. & 6 & 24 \\
\hline Chase-Dunn, C. & 5 & 14 \\
\hline \multicolumn{2}{|r|}{} \\
\hline
\end{tabular}

Figure 3 presents the research documents on Dependency Theory by affiliation of authors at Scopus. The University of Southern California leads with 12 documents, followed by Harvard University and Stony Brook University with 9 documents each.

\section{Figure 3: Documents by affiliation}

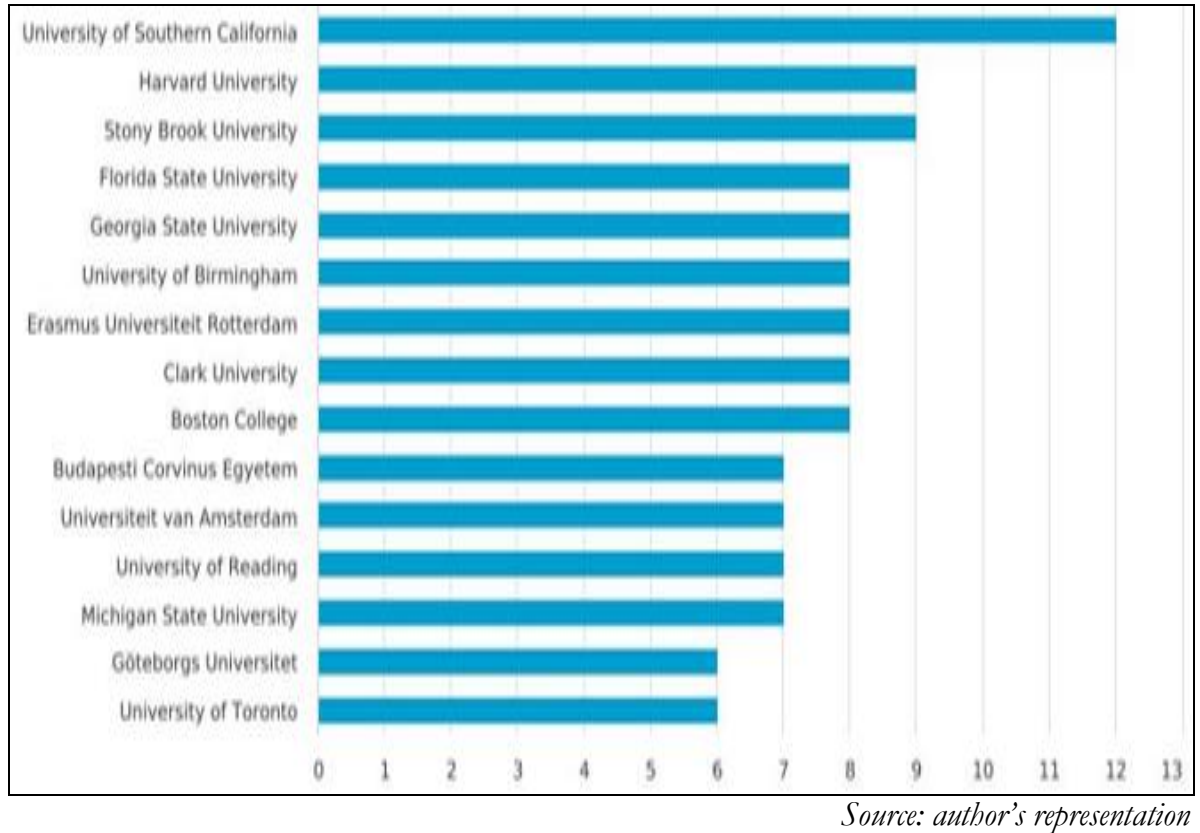

Figure 4 presents the documents by country or territory, with the United States of America having 393 documents, followed by the United Kingdom (106 documents), China (55 documents) and Australia (49 documents). 
Figure 4: Dependency theory documents by country or territory at Scopus

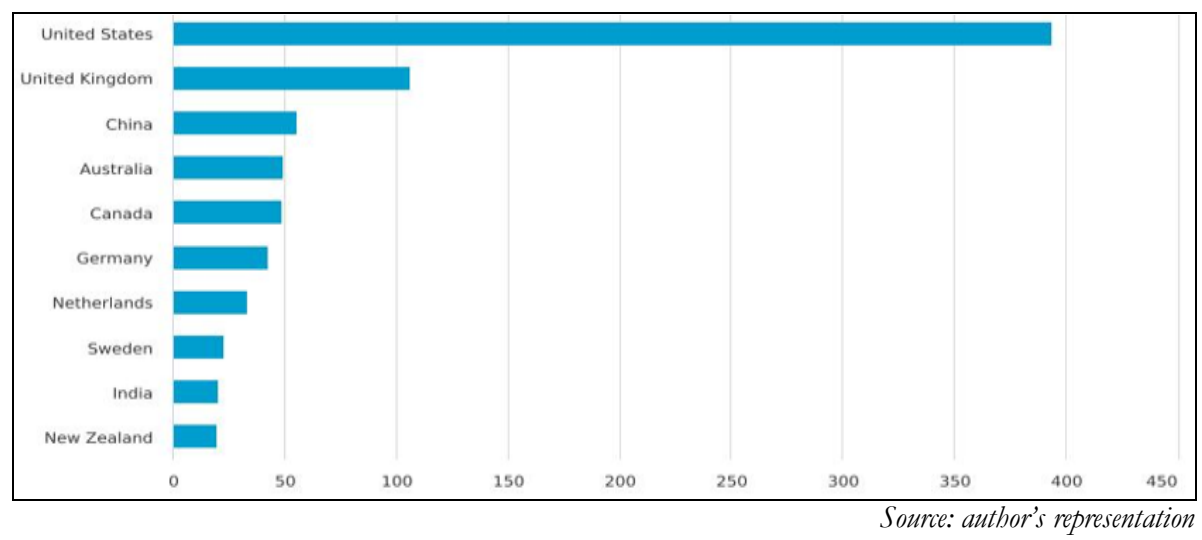

Table 4 provides a list of research documents by the top 10 subject areas.

Table 4: Number of documents based on top 10 subject areas

\begin{tabular}{|l|r|}
\hline \multicolumn{1}{|c|}{ SUBJECT AREA } & Number of documents \\
\hline Social Sciences & 598 \\
\hline Business, Management and Accounting & 303 \\
\hline Arts and Humanities & 145 \\
\hline Computer Science & 137 \\
\hline Economics, Econometrics and Finance & 130 \\
\hline Environmental Science & 92 \\
\hline Engineering & 78 \\
\hline Earth and Planetary Sciences & 53 \\
\hline Medicine & 50 \\
\hline Decision Sciences & 45 \\
\hline
\end{tabular}

Source: author's own work

Social science had 598 documents (34.2\%), followed by Business Management and Accounting with 303 documents (17.3\%), and Arts and Humanities with 145 documents $(8.3 \%)$. This mix-up of subject areas can make us consider Dependency Theory interdisciplinary in nature.

Table 5 presents the most cited research documents on Dependency Theory in different Scopus-indexed publications. As per Scopus, the Academic Citation Index (ACI) was 4 and CrossRef Index was 274, both of which were PlumX metrics (Plum Analytics, 2021). ACI help readers understand the inherent relationship and derivations between different references, and facilitates linking to further references of a particular discipline, e.g., dependency theory (Airiti Inc., 2021). The CrossRef Index is used for linking citations related to dependency theory across publishers (CrossRef, 2021). 
104 | A bibliometric analysis on dependency theory

Table 5: Most cited Scopus documents on dependency theory

\begin{tabular}{|c|c|c|c|c|c|c|c|}
\hline $\begin{array}{c}\text { Year of } \\
\text { Publication }\end{array}$ & Document Title & Authors & Journal Title & $\begin{array}{c}\text { Total } \\
\text { Citation }\end{array}$ & ACI & $\begin{array}{c}\text { CrossRef } \\
\text { Index }\end{array}$ & FWCI \\
\hline 1979 & $\begin{array}{l}\text { Structural position in } \\
\text { the world system and } \\
\text { economic growth, } \\
\text { 1955-1970: a } \\
\text { multiple-network } \\
\text { analysis of } \\
\text { transnational } \\
\text { interactions. }\end{array}$ & $\begin{array}{l}\text { Snyder } \\
\text { D., Kick } \\
\text { E.L. }\end{array}$ & $\begin{array}{l}\text { American Journal of } \\
\text { Sociology }\end{array}$ & 450 & 4 & 274 & $\mathrm{~N} / \mathrm{A}$ \\
\hline 2009 & $\begin{array}{l}\text { Board structure and } \\
\text { firm performance: } \\
\text { Evidence from } \\
\text { India's top } \\
\text { companies }\end{array}$ & $\begin{array}{l}\text { Jackling } \\
\text { B., Johl S. }\end{array}$ & $\begin{array}{l}\text { Corporate } \\
\text { Governance: An } \\
\text { International Review }\end{array}$ & 360 & & 297 & 6.24 \\
\hline 2010 & $\begin{array}{l}\text { Latin American } \\
\text { theories of } \\
\text { development and } \\
\text { underdevelopment }\end{array}$ & Kay C. & $\begin{array}{l}\text { Latin American } \\
\text { Theories of } \\
\text { Development and } \\
\text { Underdevelopment }\end{array}$ & 285 & & & 6.25 \\
\hline 2007 & $\begin{array}{l}\text { External } \\
\text { relationships and the } \\
\text { small business: A } \\
\text { review of small } \\
\text { business alliance and } \\
\text { network research }\end{array}$ & $\begin{array}{l}\text { Street } \\
\text { C.T., } \\
\text { Cameron } \\
\text { A.-F. }\end{array}$ & $\begin{array}{l}\text { Journal of Small } \\
\text { Business } \\
\text { Management }\end{array}$ & 263 & 3 & 213 & 7.57 \\
\hline 2010 & $\begin{array}{l}\text { Leveraging IT } \\
\text { capabilities and } \\
\text { competitive process } \\
\text { capabilities for the } \\
\text { management of } \\
\text { interorganizational } \\
\text { relationship } \\
\text { portfolios }\end{array}$ & $\begin{array}{l}\text { Rai A., } \\
\text { Tang X. }\end{array}$ & $\begin{array}{l}\text { Information Systems } \\
\text { Research }\end{array}$ & 240 & & 100 & 7.67 \\
\hline
\end{tabular}

Source: author's own work

\subsection{Science Mapping}

\subsubsection{Co-word analysis}

In the co-word analysis, we examined the actual content of the publications on dependency theory, which we often derived from "author keywords", and in its absence, notable words can also be extracted from "article titles," "abstracts," and "full texts" for the analysis (Donthu et al. 2021; Baker, Kumar and Pandey, 2020). In doing the keyword analysis, we considered ten occurrences as threshold. Figure 5 depicts the co-word analysis in details. 


\section{Figure 5: Co-word analysis by all keywords}

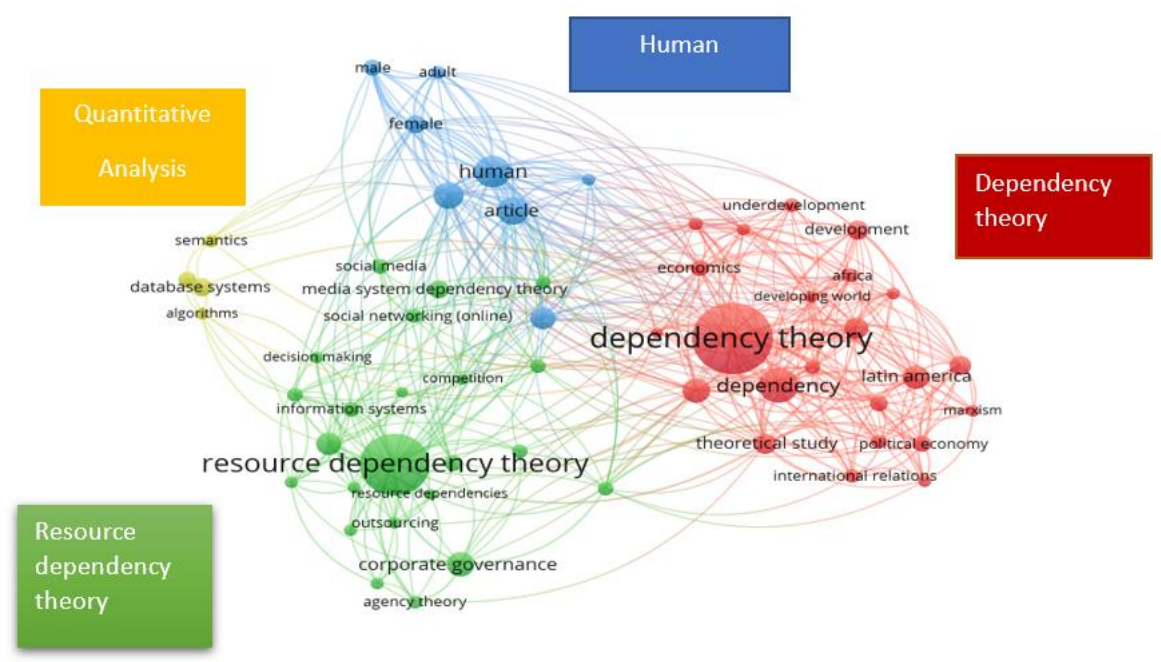

Source: author's own work

We named the red cluster "Dependency theory"; the dominant keyword was "dependency theory" (137 occurrences). In the green cluster ("Resource dependency theory"), the dominant idiom was "resource dependency theory" (113 occurrences). The blue cluster was named "Human", as this word occurred 45 times, while the last cluster was labeled "Quantitative Analysis".

\subsubsection{Citation analysis}

Citation analysis operates on the assumption that citations reflect intellectual linkages between publications in the field of dependency theory and are formed when one publication cites the other (Donthu et al. 2021; Appio, Cesaroni and Di Minin, 2014). We considered 25 authors out of 2013 authors who have at least 3 documents and 30 citations. Figure 6 show the five most influential authors and how their research works are connected. According to Donthu et al. (2021), Shandra J.M., with 10 documents till date, is the most influential author in Dependency Theory. 
106 | A bibliometric analysis on dependency theory

Figure 6: Citation analysis by authors

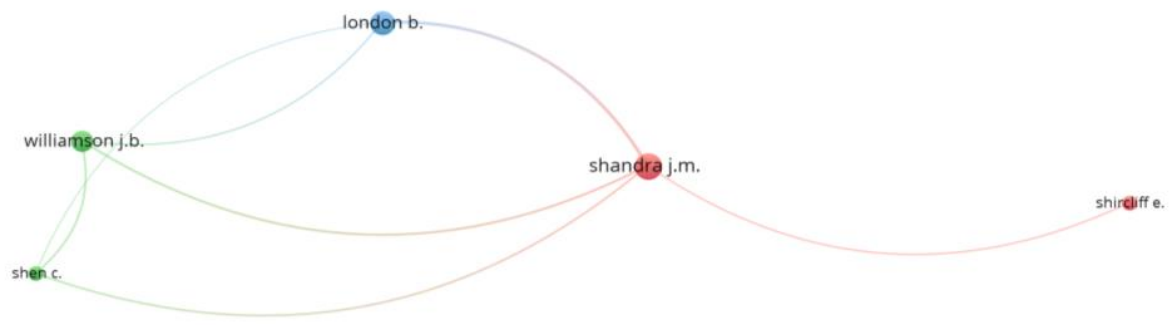

Source: author's own work

In terms of analyzing documents by source, our 1074 documents have 847 sources. Based on the filter of considering at least 3 documents of each source and the minimum number of citations of a source ( 30 citations of each source), we narrowed down our analysis to 39 sources. Out of these 39 documents, the following 13 sources were connected (Figure 7).

Figure 7: Citation analysis by source

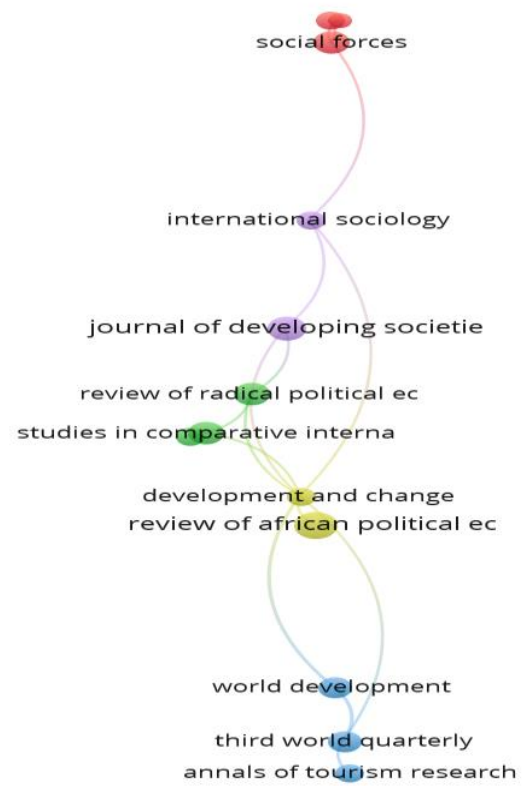

Source: author's own work 
Out of these sources, social forces are the most influential, with 6 documents and 489 . In terms of citation analysis based on country, we considered minimum 3 documents per country and at least 30 citations. According to this threshold, we considered 36 countries (Figure 8). The USA dominated with 403 documents.

Figure 8: Citation analysis by country

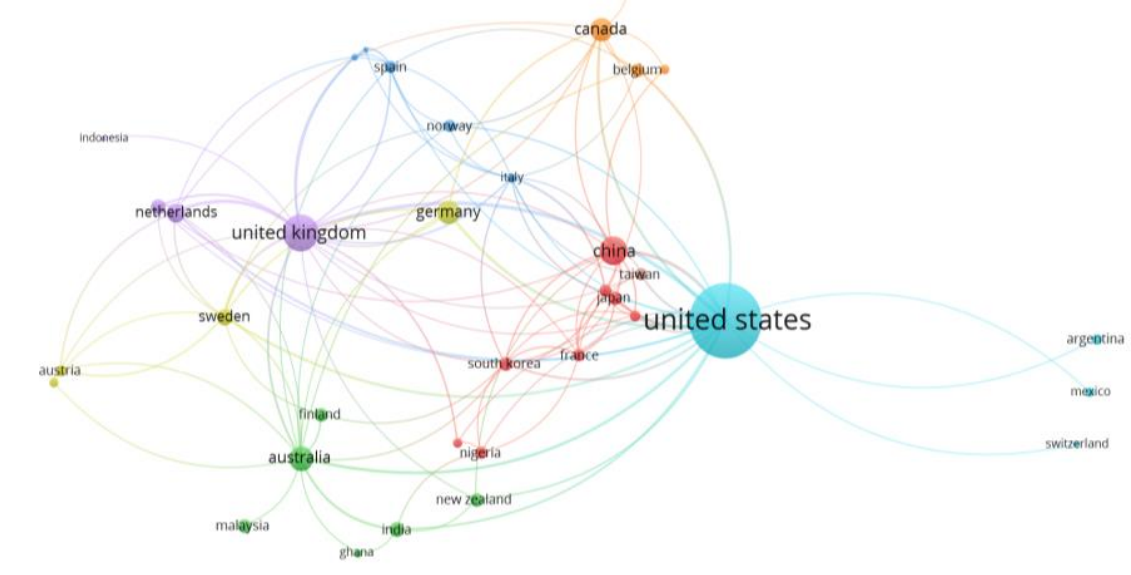

A vosviewer

Source: author's own work

\subsubsection{Co-citation analysis}

In a co-citation network of dependency theory, two publications are connected when they co-occur in the reference list of another publication and co-citation analysis concentrates only on highly-cited publications (Donthu et al,2021; Hjørland, 2013). The benefit of using co-citation analysis is that, in addition to finding the most influential publications in this field, we can also discover thematic clusters involved in this area (ibid). In terms of selecting minimum number of citations of a cited reference, we considered 20 cited references. Figure 9 shows that the research paper "Resource Dependence Theory: A Review" (Hillman, A.J., Withers, M.C. and Collins, B.J., 2009) had 35 co-citations in highly cited publications. 
108 | A bibliometric analysis on dependency theory

Figure 9: Co-citation analysis by cited references

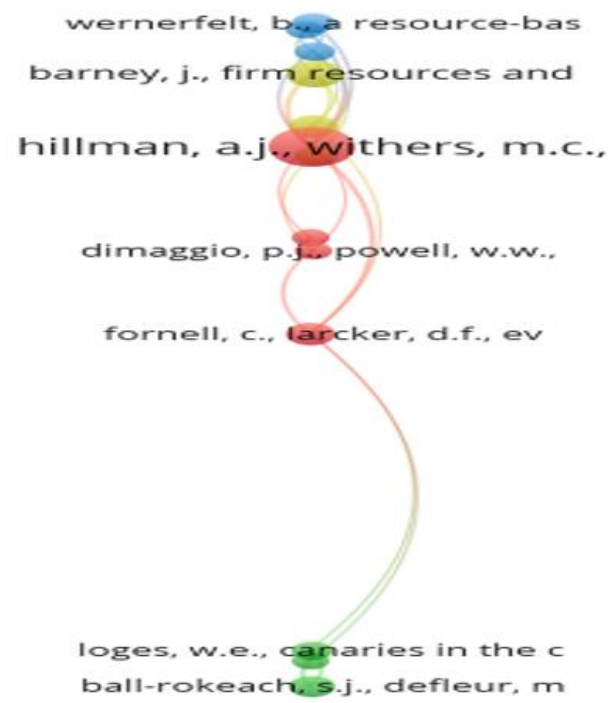

Source: author's own work

In terms of co-cited sources of publications, we considered 177 sources that had at least 30 co-citations (Figure 10). With 695 citations, the "Strategic Management Journal" was the leading source that was co-cited by other reputed sources.

\section{Figure 10: Co-citation analysis by cited sources}

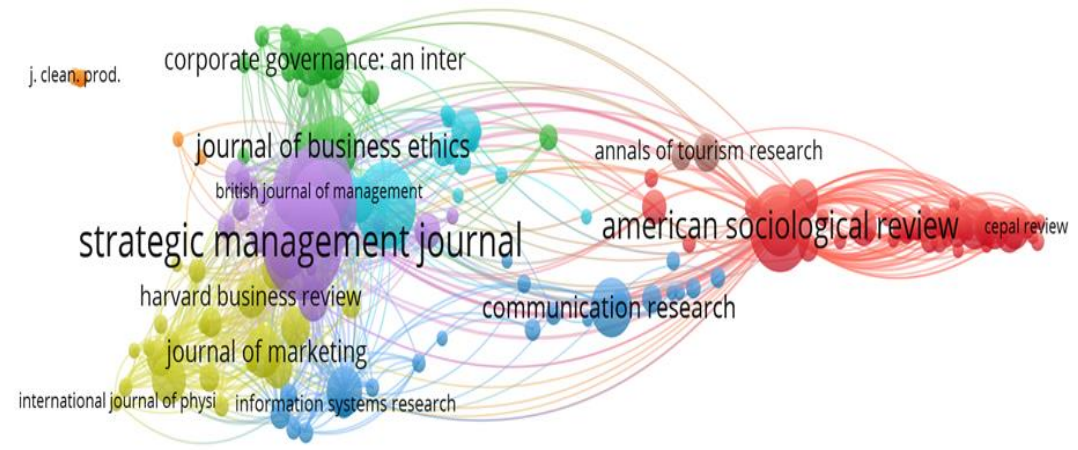

Source: author's own work 


\subsubsection{Bibliographic Coupling}

Bibliographic coupling is the third analysis of science mapping that operates on the assumption that two publications sharing common references are also similar in their content (Donthu et al., 2021; Weinberg, 1974).

Firstly, we conducted bibliographic coupling based on 120 documents which were interconnected and had 360 citations (Figure 11). Among the six clusters, the purple cluster, led by Jackling's article (2009, 361 citations), was significant.

\section{Figure 11: Bibliographic coupling analysis based on documents}

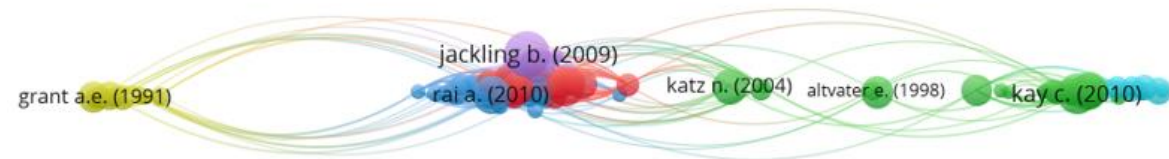

Source: author's own work

Secondly, we analyzed bibliographic coupling based on sources. We considered 39 sources which had 3 published documents and at least 30 citations in Scopus (Figure 12). The dominant cluster (red one) was led by the International Journal of Human Resource Management (8 documents).

Figure 12: Bibliographic coupling analysis based on sources

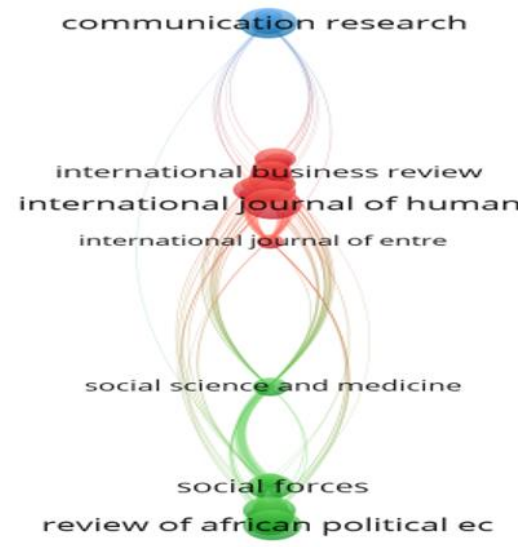


110 | A bibliometric analysis on dependency theory

Finally, we conducted a bibliographic coupling analysis based on countries. Based on the threshold of 3 documents and 30 citations from each country, we selected 37 countries (Figure 13). The red cluster is the biggest one, led by the United States with 403 documents, and connected to three other clusters (green, blue and yellow).

\section{Figure 13: Bibliographic coupling analysis based on countries}

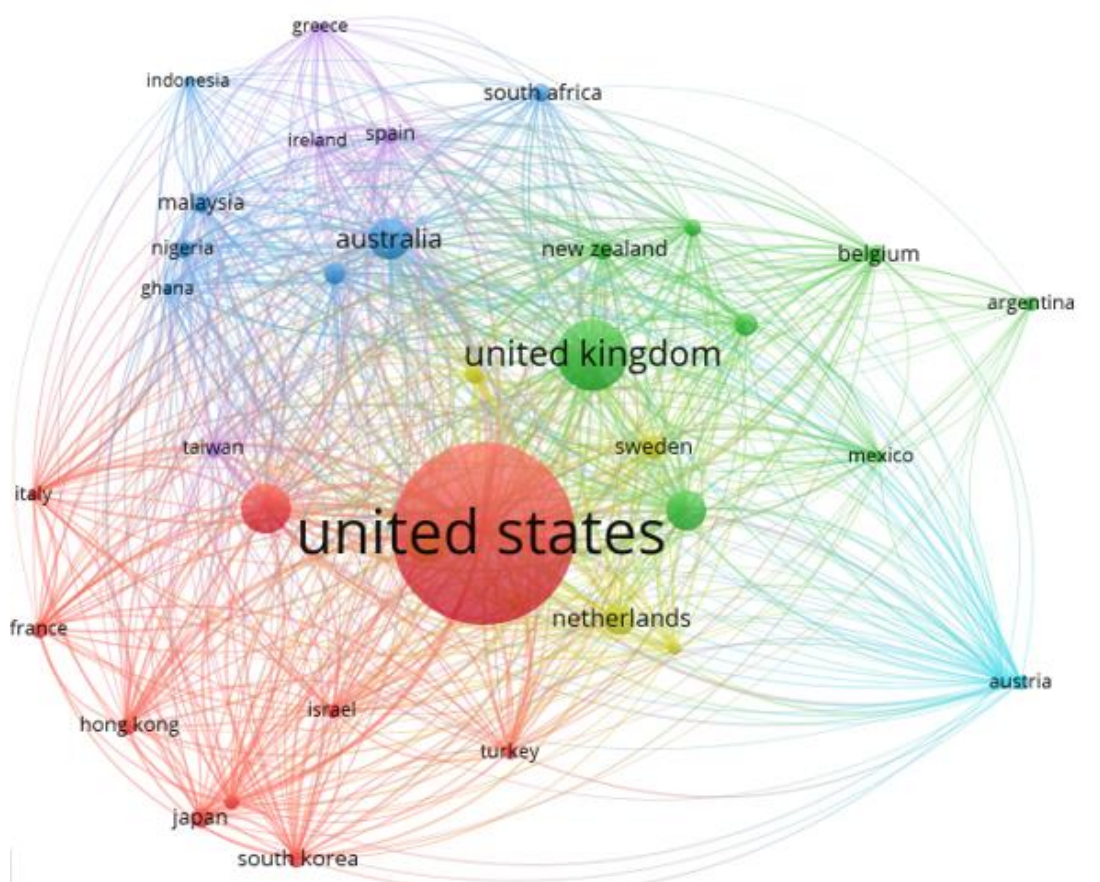

Source: author's own work.

\subsubsection{Co-Authorship Analysis}

We conducted co-authorship analysis which is the formal way of intellectual collaboration among scholars in the field of dependency theory in order to understand how scholars interact amongst themselves (Acedo et al., 2006; Donthu et al., 2021). We considered at least 2 documents and 20 citations and out of them, 6 authors met the criteria of making the co-authorship analysis (Figure 14). It can seen that all six authors had combined research works among themselves which made the theory significant. 


\section{Figure 14: Co-authorship analysis based on authors}

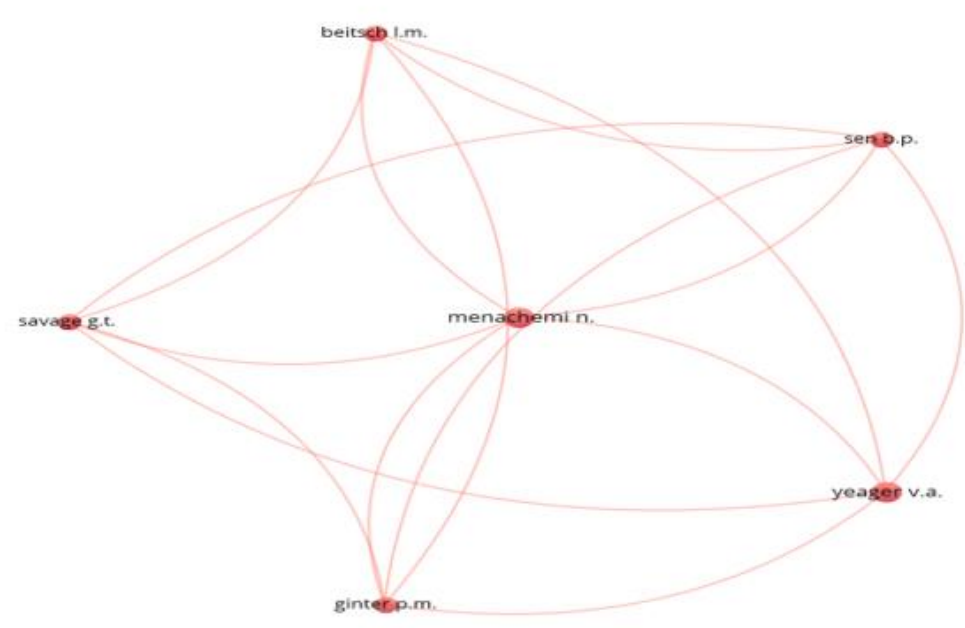

Source: author's own work

\section{Significance, Limitations, and Future Research}

Conducting a bibliometric analysis on dependency theory is a contributory in nature by connecting the relevant fields under the single domain to picture this theory as interdisciplinary in nature. This analysis has identified and explained significant authors, research documents, published sources and contributory countries in the field of dependency theory through extensive performance analysis and science mapping. These analyses clearly showed the significance of this theory in the field of research.

In conducting bibliometric analysis, we considered research documents that were in final stage and written in English which narrowed down our paper numbers from 1160 to 1074 . Also, while doing the analysis, we considered the top cited research documents and showed the performance analysis and science mapping. Also, we only considered documents that were indexed at Scopus database.

Our bibliometric analysis can pave the way to conduct more interdisciplinary research works. Future research can also include a comparative bibliometric analysis between Scopus database documents and other databases, e.g. Web of Science, Google Scholar etc.

\section{Conclusion}

The study concludes that dependency theory is a significant theory in economics and has significant implications in different research publications. This bibliometric analysis surfaces the significance of this theory which would attract researchers in incorporating 
more interdisciplinary research. Different performance analysis parameters identified the quantitative aspects and significances of different scholarly contributions from many corners of the world. The science mapping articulately presents the vastness of this theory by creating networks of documents, authors, organizations and countries. Positive growth in research and immense significance of published works portray more growth as research interest by future researchers.

\section{Authorship}

S.M.A. and T.A. contributed equally to the study. S.M.A. and T.A. conceptualized and designed the study. S.M.A. was responsible for overall project supervision. S.M.A. and T.A. were responsible for data citation and analyses. S.M.A. led manuscript preparation and both authors contributed to the manuscript's drafting. T.A. did proofreading.

\section{Acknowledgements}

The authors wish to thank their family members for supporting them while preparing the manuscript.

\section{Funding}

The authors received no financial support for the research, authorship and publication of the manuscript. This research is a self-funded research.

\section{Declaration of conflicting interests}

The author declares no conflicting interests.

\section{References}

Acedo, F. J., Barroso, C., Casanueva, C., \& Galán, J. L. (2006). Co-Authorship in Management and Organizational Studies: An Empirical and Network Analysis. Journal of Management Studies, 43(5), 957-983. https://doi.org/10.1111/j.14676486.2006.00625.x

Airiti Inc. (2021). Airiti Inc. Retrieved July 5, 2021, from http://www.airiti.com/ en/page_aci.html

Appio, F. P., Cesaroni, F., \& Di Minin, A. (2014). Visualizing the structure and bridges of the intellectual property management and strategy literature: A document cocitation analysis. Scientometrics, 101(1), 623-661. https://doi.org/10.1007/s11192014-1329-0

Arezki, R., Hadri, K., Loungani, P. and Rao, Y. (2013). Testing the Prebisch-Singer Hypothesis since 1650: Evidence from Panel Techniques that Allow for Multiple Breaks; by Rabah Arezki, Kaddour Hadri, Prakash Loungani, Yao Rao; IMF Working Paper 13/180; August 1, 2013. [online] Available at: https://www.imf.org/external/ pubs/ft/wp/2013/wp13180.pdf [Accessed 19 May 2021]. 
Baker, H. K., Kumar, S., \& Pandey, N. (2020). A bibliometric analysis of managerial finance: A retrospective. Managerial Finance, 46(11), 1495-1517. https://doi.org/ 10.1108/MF-06-2019-0277

Booth, D. (1985). Marxism and development sociology: Interpreting the impasse. World Development, 13(7), 761-787. Scopus. https://doi.org/10.1016/0305750X(85)90107-X

Bouyssou, D., \& Marchant, T. (2011). Ranking scientists and departments in a consistent manner. Journal of the American Society for Information Science and Technology, 62(9), 1761-1769. https://doi.org/10.1002/asi.21544

Brereton, P., Kitchenham, B. A., Budgen, D., Turner, M., \& Khalil, M. (2007). Lessons from applying the systematic literature review process within the software engineering domain. Journal of Systems and Software, 80(4), 571-583. https:// doi.org/10.1016/j.jss.2006.07.009

Brown, W. A. (2005). Exploring the association between board and organizational performance in nonprofit organizations. Nomprofit Management and Leadership, 15(3), 317-339. Scopus. https://doi.org/10.1002/nml.71

CrossRef. (2021). You are Crossref [Website]. Crossref. Retrieved July 5, 2021, from https://www.crossref.org/

Donthu, N., Kumar, S., Mukherjee, D., Pandey, N., \& Lim, W. M. (2021). How to conduct a bibliometric analysis: An overview and guidelines. Journal of Business Research, 133, 285-296. https://doi.org/10.1016/j.jbusres.2021.04.070

Dos Santos, T. (2021). The Structure of Dependence. Retrieved June 20, 2021, from https://www.jstor.org/stable/1815811

Egghe, L. (2006). Theory and practice of the g-index. Scientometrics, 69(1), pp. 131-152, doi:10.1007/s11192-006-0144-7.

Eldermire, E. (2021). LibGuides: Measuring your research impact: i10-Index. https://guides.library.cornell.edu/impact/author-impact-10 [2021-05-30].

Ferraro, V. (2019). "Dependency Theory: An Introduction," Vincent Ferraro, Mount Holyoke College, July 1966. [online] Mtholyoke.edu. Available at: https://www. mtholyoke.edu/acad/intrel/depend.htm [Accessed 19 Jun. 2021].

Firebaugh, G. (1999). Empirics of world income inequality. American Journal of Sociology, 104(6), 1597-1630. Scopus. https://doi.org/10.1086/210218

Harvey, D.I., Kellard, N.M., Madsen, J.B. and Wohar, M.E. (2010). The PrebischSinger Hypothesis: Four Centuries of Evidence. Review of Economics and Statistics, 92(2), pp.367-377.

Hays, D.G. 1964, "Dependency Theory: A Formalism and Some Observations. MEM RM-4087-PR", Memorandum RM-.Rand Corporation, vol. 42, pp. 1-39.

Hillman, A. J., Withers, M. C., \& Collins, B. J. (2009). Resource Dependence Theory: A Review. Journal of Management, 35(6), 1404-1427. https://doi.org/10.1177/ 0149206309343469

Hirsch, J. E. (2005). An index to quantify an individual's scientific research output. Proceedings of the National Academy of Sciences, 102(46), pp. 16569-16572, doi:10.1073/pnas.0507655102.

Hjørland, B. (2013). Facet analysis: The logical approach to knowledge organization. Information Processing \& Management, 49(2), 545-557. https://doi.org/10.1016/ j.ipm.2012.10.001 
114 | A bibliometric analysis on dependency theory

Jackling, B., \& Johl, S. (2009). Board structure and firm performance: Evidence from India's top companies. Corporate Governance: An International Review, 17(4), 492-509. Scopus. https://doi.org/10.1111/j.1467-8683.2009.00760.x

Katz, N., Lazer, D., Arrow, H., \& Contractor, N. (2004). Network theory and small groups. Small Group Research, 35(3), 307-332. Scopus. https://doi.org/10.1177/ 1046496404264941

Kay, C. (2010). Latin American theories of development and underdevelopment (p. 295). Scopus. https://doi.org/10.4324/9780203835418

Kleemeier, L.L. (1978). "Empiricai Tests of Dependency Theory: A Second Critique of Methodology", The Journal of Modern African Studies, vol. 16, no. 4, pp. 701-704.

Norouzi, M., Chàfer, M., Cabeza, L. F., Jiménez, L., \& Boer, D. (2021). Circular economy in the building and construction sector: A scientific evolution analysis. Journal of Building Engineering, 44, 102704. https://doi.org/10.1016/ j.jobe.2021.102704

Plum Analytics. (n.d.). About PlumX Metrics_Plum Analytics. Retrieved June 21, 2021, from https://plumanalytics.com/learn/about-metrics/

Rai, A., \& Tang, X. (2010). Leveraging IT capabilities and competitive process capabilities for the management of interorganizational relationship portfolios. Information Systems Research, 21(3), 516-542. Scopus. https://doi.org/10.1287/ isre. 1100.0299

Roşca, V. I. (2017). The Europeanisation of Romanian football: What Do UEFA country coefficients reveal?. Management \& Marketing. Challenges for the Knowledge Society, 12(4), 652-673. Doi: 10.1515/mmcks-2017-0038

Roşca, V. I. (2018a). Theoretical Considerations on the Evolution of Sombart's CenterPeriphery Model. Revista de Management Comparat International, 19(1), 77-87.

Roşca, V. I. (2018b). The Influence of European Cup Performances on Domestic Stadium Attendances in Romanian Football. In: Proceedings of the International Conference on Business Excellence (Vol. 12, No. 1, pp. 875-884). DOI: 10.2478/picbe-20180078

Roşca, V. I. (2018c). Relația centru-periferie: geografii şi metafore. In: Boşca, L.C., Vreja, L.O. (Eds.), Filosofie şi Economie. Temeiuri axiologice ale comportamentului economic. Volumul 4, Bucharest: Editura ASE (pp. 165-172).

Sahlins, M. (1999). What is anthropological enlightenment? Some Lessons of the Twentieth Century. Annual Review of Anthropology, 28, i-xxiii. Scopus. https://doi.org/10.1146/annurev.anthro.28.1.0

Scimago Lab. (n.d.). Scimago Journal \& Country Rank. Retrieved June 21, 2021, from https://www.scimagojr.com/

Scopus. (n.d.). Scopus_Compare sources. Retrieved June 21, 2021, from https://wwwscopus-com.ezproxy.its.uu.se/source/eval.uri?isCompareJournal=true\&source $\mathrm{Ids}=17649,55289,24840,27938,18500157300,29448,17530,26587,27217,16885 \& \mathrm{st}$ yleIndexes $=0,0,0,0,0,0,0,0,0,0$

Singer, H., (1950). The Distribution of Gains between Investing and Borrowing Countries, American Economic review, Papers and Proceedings, 40, 473-485.

Snyder, D., \& Kick, E. L. (1979). Structural position in the world system and economic growth, 1955- 1970: A multiple-network analysis of transnational interactions. 
American Journal of Sociology, 84(5), 1096-1126. Scopus. https://doi.org/ $10.1086 / 226902$

Street, C. T., \& Cameron, A.-F. (2007). External relationships and the small business: A review of small business alliance and network research. Journal of Small Business Management, 45(2), 239-266. Scopus. https://doi.org/10.1111/j.1540627X.2007.00211.x

United Nations Secretariat (UN DESA) (2021). World Economic Situation Prospects. [online] United Nations. Economic Analysis and Policy Division (EAPD) of the Department of Economic and Social Affairs of the United Nations Secretariat (UN DESA). Available at: https://www.un.org/development/desa/dpad/wpcontent/uploads/sites/45/WESP2021_ANNEX.pdf.

Weinberg, B. H. (1974). Bibliographic coupling: A review. Information Storage and Retrieval, 10(5), 189-196. https:/ / doi.org/10.1016/0020-0271(74)90058-8

Your Articles Library. (2015, April 4). Dependency Theory: Critical Appraisal, Importance and Limitations. Your Article Library. https://www.yourarticlelibrary.com/international-politics/dependency-theory-critical-appraisalimportance-and-limitations/48481 